\title{
Synthesis and complexation studies on 1,4-dinaphthocrown ether
}

\author{
A. Manjula and M. Nagarajan \\ School Of Chemistry, University Of Hyderabad, Hyderabad-500046, India \\ E-mail: manjula@iict.nic.in
}

\begin{abstract}
Dedicated to Professor T. R. Govindachary on the occasion of his $85^{\text {th }}$ birthday
(received 01 Apr 01; accepted 22 Nov 01; published on the web 30 Nov 01)
\end{abstract}

\begin{abstract}
A simple and straightforward synthesis of hitherto unreported dinaphthocrown ether was accomplished and its binding studies with electron deficient hosts were investigated.
\end{abstract}

Keywords: 1,4-Dinaphthocrown ether, complexation, binding studies

\section{Introduction}

Interactions between aromatic molecules have been known and studied for over half a century. Strong attractive interactions between $\pi$-systems are a class of noncovalent intermolecular forces to reckon with in chemistry, biology and materials science as they control a range of recognition and self-assembly phenomena such as vertical base pair interactions which stabilize the DNA double helix and also intercalation of drugs into DNA, ${ }^{1}$ tertiary structure of proteins, -porphyrin aggregation, ${ }^{2}$ packing of aromatic molecules in crystals, ${ }^{3}$ complexation in many host-guest systems especially with respect to conformational preferences and binding properties of polyaromatic macrocycles $^{4}$ and template directed synthesis. ${ }^{5}$

Crown ethers and cyclophanes, especially the ones possessing aromatic moieties, are known to form charge transfer complexes with a variety of guests. These macrocycles were used to study complexation of diverse guests to provide new insights into noncovalent binding interactions, chiefly cation- $\pi$ interactions. These interactions involve the stabilisation of a positive charge by the face of an aromatic ring. ${ }^{6}$ The cation- $\pi$ interactions are important binding forces in biological receptors like acetyl choline. Sufficiently electron deficient neutral molecules have been shown to bind to the above set of hosts by $\pi$ type interactions. ${ }^{7}$

Stoddart ${ }^{8}$ has extensively investigated the interaction of dibenzo crowns 1 (Fig. 1) with the dipyridinium cations, diquat 2 and paraquat 3. A study of the complexation of a family of dibenzocrowns and diquat in acetone divulged that the association constants were sensitive to the polyether chain length. 9,10 


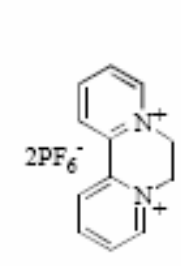

2

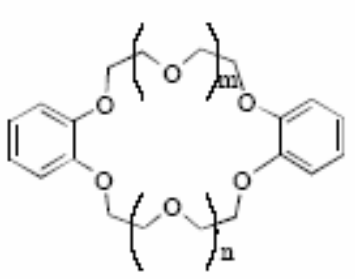

1

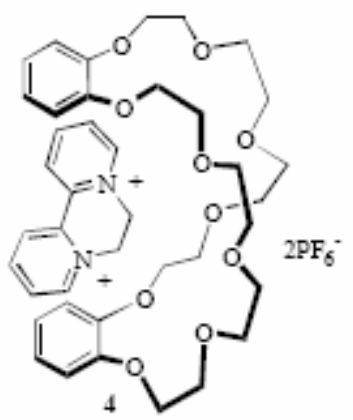

\section{Figure 1}

An extension of the complexation to the macrocyclic cavity bisparaphenylene-[34]-crown-10 (BPP34C10, 5, Fig. 2), generated a highly ordered superstructure, in which the rod like paraquat lies in the cavity of BPP34C10 centrosymmetrically with the methyl groups facing the polyether linkages. 6, (Fig. 2). ${ }^{11,12}$ This was later extrapolated to some dinaphtho crowns also. ${ }^{13,14}$

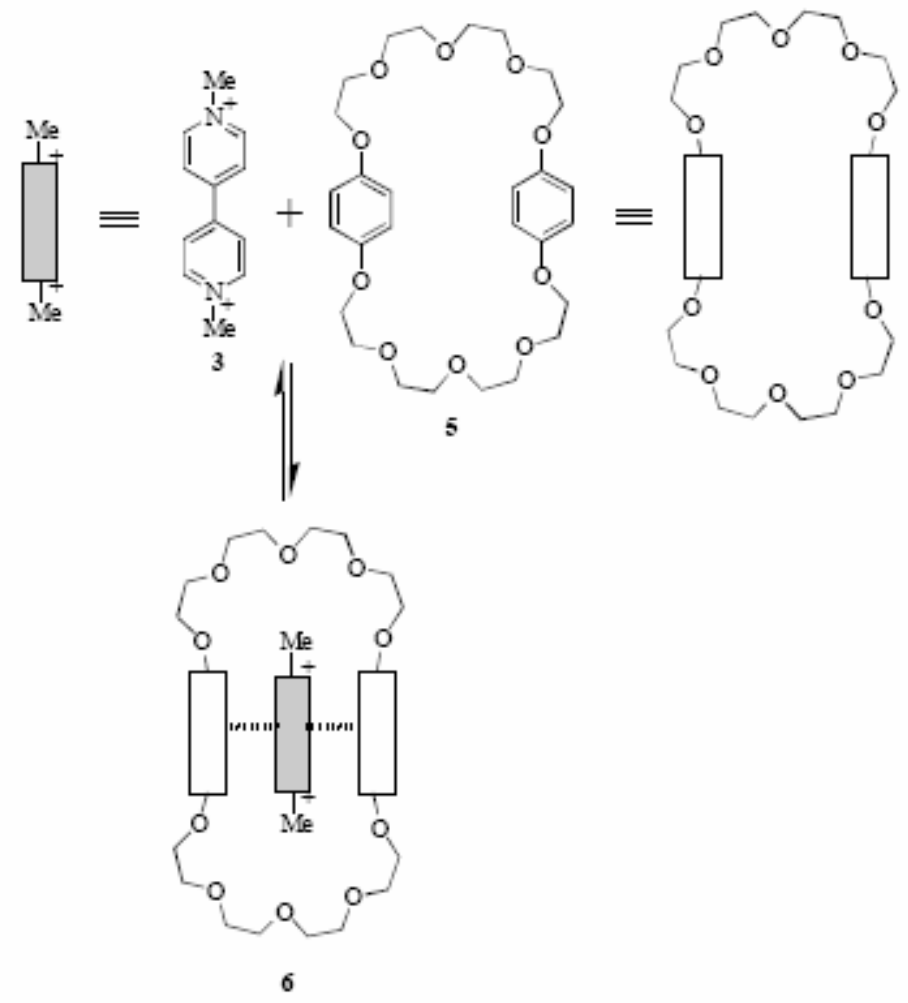

\section{Figure 2}

The above mentioned centrosymmetrically threaded structures form the building blocks for the self-assembly of supramolecular array of interlocked molecules, like the catenanes and rings trapped on the spindles of the dumbbell shaped components, called the rotaxanes (the above structures are often referred to by the term pseudorotaxanes as they lack the bulky stoppers of a dumbbell, indicating that they are free to dissociate). ${ }^{15}$ 
Many examples of these archetypal interlocked molecules have been reported over the last decade, particularly after the concept of chemical template based self-assembly became widely accepted as a useful paradigm in constructing chemical systems. ${ }^{16}$

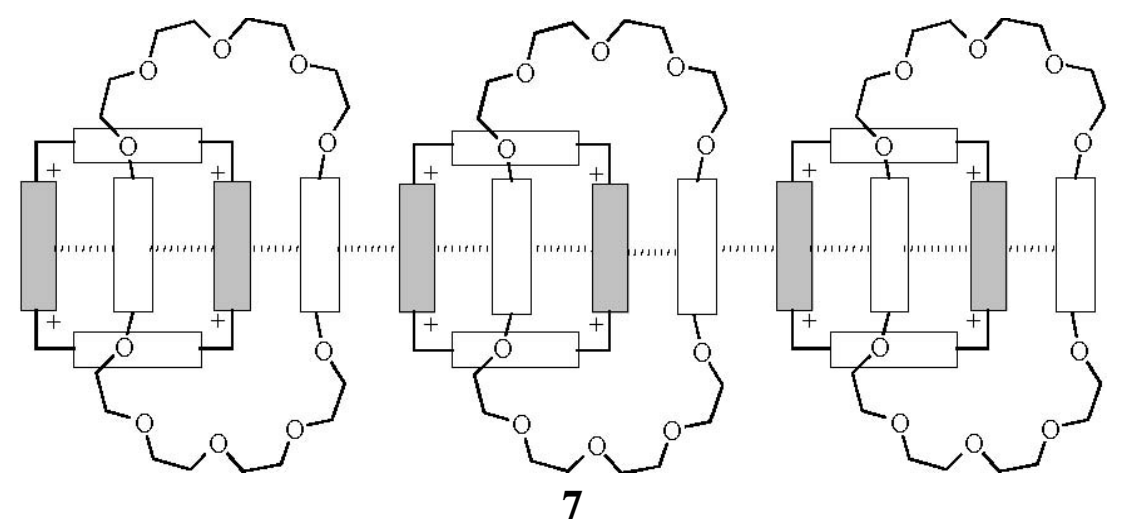

Figure 3

The $\pi-\pi$ interactions have been exploited to the fullest extent in the process of construction of the [2], [3] and [5] catenanes. X-ray analysis of the crystal structure of the [2]-catenane 6 revealed that mutual recognition between the appropriately located $\pi$-donors and $\pi$-acceptors is in action within and beyond the molecule forming a continuous $\pi$-donor/ $\pi$-acceptor stack of [2]catenane 7 (Fig. 3). ${ }^{17}$

\section{Figure 4}

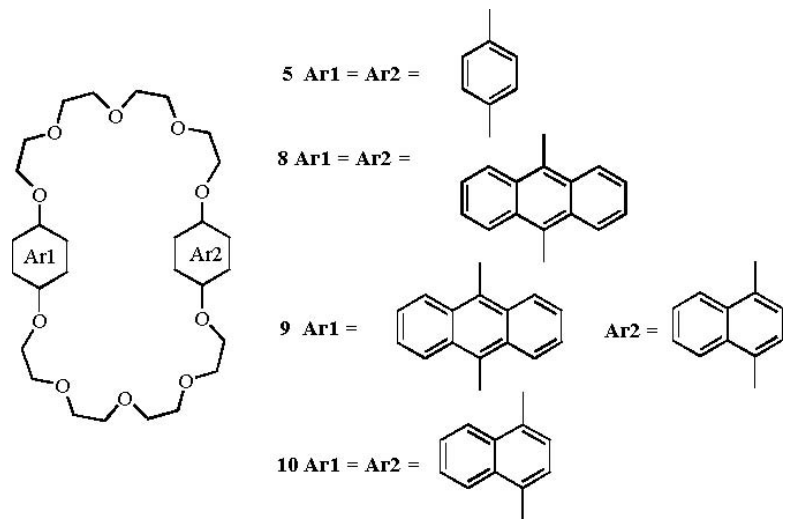

Of particular interest to us were the results of a study made on the effect of the spacer unit of the $\pi$-donor macrocycle on the catenation yields. ${ }^{18}$ The study on the macrocycles ranging from BPP31C9 to BPP46C14 revealed the ideal framework for catenation to be BPP34C10 (70\% yield). A smaller size of the cavity is too tight and discomforting for inclusion of the precursor and the larger ones have poor intercomponent recognition due to their inherent flexibility.

This provided the necessary impetus for us to synthesise the hitherto unreported 1,4dinaphtho-34-crown-10 (1,4-DN34C10, 10) and study its complexation capabilities with $\pi$ acceptor guests. In addition to providing an excellent framework for $\pi$-stacking complexation, 1,4-DN34C10 could also prove to be a good probe for cation detection. Desvergne has shown 
that BPP34C10, ${ }^{19}$ its corresponding anthracene analog $8,{ }^{20}$ and a novel dissymmetric coronand $\mathbf{9},{ }^{21}$ display specific optical responses towards alkali and alkaline earth metal cations (Fig. 11). Thus, 10 can also serve as a fluorescent probe for cation detection. With this primary aim we set out to synthesise 1,4-DN34C10 and study its complexation properties.

\section{Results and Discussion}

A survey of the literature revealed that the most convenient starting materials for 1,4-crowns were either 1,4-quinones ${ }^{20}$ or 1,4-diols. ${ }^{22}$ In our case, the undesirable properties of 1,4naphthoquinone and the unstable nature of of the 1,4-naphthalenediol precluded their use. Therefore, the starting material chosen was the 4-bromo-1-naphthol. It was benzylated to get 4benzyloxy-1-bromonaphthalene 11. On reaction with tetraethylene glycol, 11 yielded two products. ${ }^{23}$ Yield of the desired bis ether $\mathbf{1 2}$ was $38 \%$. The ${ }^{1} \mathrm{H}$ NMR spectrum of $\mathbf{1 2}$ showed the vicinal protons $\mathrm{H}-2$ and $\mathrm{H}-3$ of naphthalene ring at $\delta 6.73-6.64$ as a quartet, whereas the other aromatic protons resonated at $\delta 8.30-7.36$ ( 2 multiplets). The benzylic $-\mathrm{CH}_{2}$ - appeared at $\delta 5.17$ as singlet and the glycol unit displayed the usual AA'XX' pattern. The ${ }^{13} \mathrm{C}$ NMR spectrum showed 11 aromatic signals and 5 aliphatic signals indicative of the symmetry present in the molecule. The elemental analysis of $\mathbf{1 2}$ was also in agreement with its structure. The monosubstituted product $\mathbf{1 3}$ was also obtained and characterized routinely.

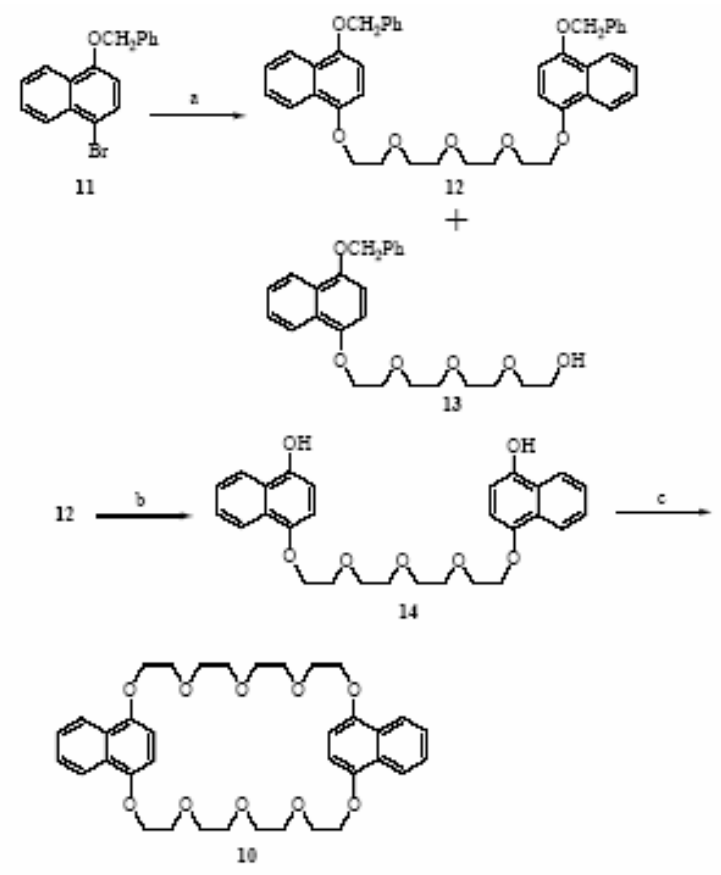

Scheme 1. Reagents and conditions: a) tetraethylene glycol, NaH, CuI, DMF, $120^{\circ}$, 48h; b) $20 \%$ $\mathrm{Pd}(\mathrm{OH})_{2}$, EtOAc, $\mathrm{H}_{2}, 55 \mathrm{psi}$, 6h; c) tetraethylene glycol ditosylate, $\mathrm{Cs}_{2} \mathrm{CO}_{3}, \mathrm{CsOTs}, \mathrm{nBu}_{4} \mathrm{NI}$, DMF, $110^{\circ}, 36 \mathrm{~h}$. 
Cleavage of the benzyl ether was then taken up. Use of $10 \% \mathrm{Pd} / \mathrm{C}$ and $\mathrm{H}_{2}$ in ethyl acetate resulted in incomplete and inconsistent cleavage of the benzyl ether. When $20 \% \mathrm{Pd}(\mathrm{OH})_{2} / \mathrm{C}$ (Pearlman's catalyst) $^{24}$ in ethyl acetate at 55 psi $\mathrm{H}_{2}$ pressure was employed, the benzyl ether cleaved readily and cleanly. The presence of the $-\mathrm{OH}$ stretch in the IR spectrum and the absence of benzylic signals in the ${ }^{1} \mathrm{H}$ NMR spectrum of the product were clear indicators of the cleavage. Interestingly, the vicinal signals corresponding to $\mathrm{H}-2$ and $\mathrm{H}-3$ of the naphthyl ring were now seen as distinct doublets at $\delta 6.66-6.61$ and $\delta 6.46-6.41$. Since the dinaphthol 14 was unstable, it was processed immediately.

The dinaphthol 14 was then heated with tetraethylene glycol ditosylate and sodium hydride in DMF for $72 \mathrm{~h}$. The crude product obtained was chromatographed to yield a white solid in $9 \%$ yield. Its IR spectrum lacked the $-\mathrm{OH}$ stretching frequency but displayed a very strong band at $1099 \mathrm{~cm}^{-1}$ for the ether linkage. The ${ }^{1} \mathrm{H}$ NMR spectrum was highly symmetrical. The aromatic signals showed two quartets at $\delta 8.18-8.14$ and 7.38-7.33 and a singlet at $\mathrm{d} 6.42$, all integrating equally. The singlet represents the vicinal $\mathrm{H}-2$ and $\mathrm{H}-3$ protons. The high degree of symmetry is also a feature of the ${ }^{13} \mathrm{C}$ NMR spectrum, where a total of 8 carbon signals appeared, 5 being aromatic and 3 aliphatic. All the above features are indicative of the formation of the desired macrocycle 10. Further proof came from a satisfactory elemental analysis and a molecular ion in the mass spectrum at $\mathrm{m} / \mathrm{z} 636$.

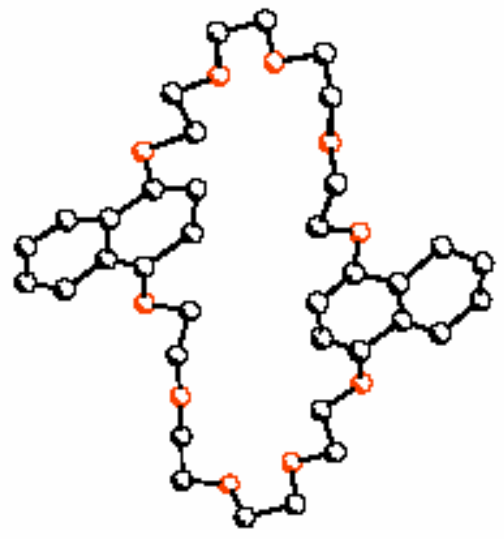

(a)

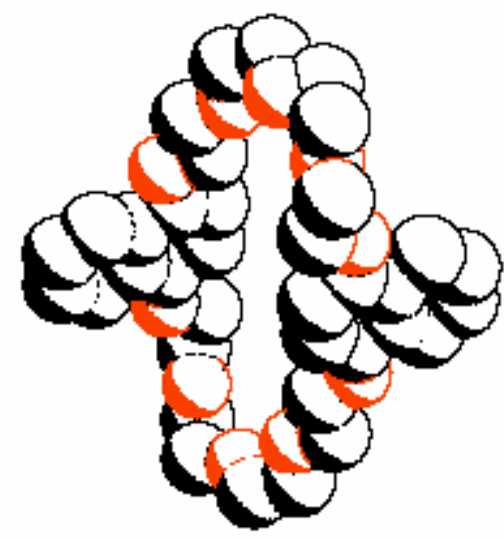

(b)

Figure 5. X-ray crystal structure of DN34C10. (a) A ball and stick representation (b) A space filling representation.

Having achieved the synthesis of 10, attempts were now focused toward improving the yield. Carrying out the reaction under high dilution condition improved the yield to $27 \%$, while a combination of using cesium carbonate and high dilution pushed it up to $32 \%{ }^{24}$ The reaction time was also reduced by half. These details are presented in the experimental section.

\section{Crystal structure of 1,4-DN34C10}

The crystal structure of 1,4-DN34C10 determined by X-ray diffraction methods (isotropic, $\mathrm{R}=$ 
0.14) at $\mathrm{rt}$ revealed that the host belongs to the monoclinic system and crystallises in the centrosymmetric space group, $\mathrm{P} 2{ }_{1} / \mathrm{n}$. The mean planes of the naphthalene rings are almost parallel with an interplanar angle of $2.64^{\circ}$. The two rings within the molecule are offset, the distance between the centroids of the two nearest rings being $7.3 \AA$ and the farthest $10.7 \AA$. The crystal structure discloses that the host has a preorganised $(14.5 \times 4.5 \AA)$ cavity similar to that of the BPP34C10 (4) cavity. ${ }^{22}$ This is, however, not the case with 1,5-dinaphtho-crowns ${ }^{13}$ and the dissymmetric crown $9^{21}$ which fill their own cavity as a result of the T-geometry adopted by the aromatic rings. Translation related molecules are stacked along the $b$ axis with the stacking distance between the aromatic rings being $5.12 \AA$. The $2_{1}$ screw related molecules exhibit herringbone interactions between the farthest naphthalene rings.

\section{Complexation Studies}

Having achieved a simple and facile synthesis of 1,4-DN34C10, attention was now focused on its complexing ability. The UV spectrum of 1,4-DN34C10 (in acetonitrile) was found to be sensitive to the addition of $\mathrm{Na}^{+}$ions. The changes in the spectra can be attributed to the conformational reorganization due to complexation. However, the changes were small and therefore no attempts were made to determine the $\mathrm{Na}^{+}$-crown association constants. Also, the cation complexes could not be isolated.

The complexation of 1,4-DN34C10 with organic cations and neutral guests was then explored. Since the host has electron rich naphthalene rings, the guests explored for complexation were the ones that were electron deficient. The guests examined were the quinones, TCNQ, aromatic cations and electron deficient aromatic nitro compounds. Amongst the quinones investigated, only DDQ showed a clear charge transfer complex formation. However, the complex was not of a definite stoichiometry. All other quinones examined $(9,10-$ anthraquinone, 1,4-benzoquinone and 9,10-phenanthrenequinone) and TCNQ did not show any influence on the UV spectrum of 10. The addition of quinones, however, showed a quenching influence on the naphthyl fluorescence. The preferred guests were those that were not only electron deficient and but also the ones that had good $\pi$-stacking capabilities like paraquat $[1,1$ dimethyl-4,4-bipyridinium bis(hexafluorophosphate), 15] a well tested classical example, phenquat [5,6-dihydropyrazino[1,2,3,4-1mn][1,10]phenanthrolinediium bis(hexafluorophosphate), 16] and TetNF [2,4,5,7-tetranitrofluorenone, 17] (Fig. 6).

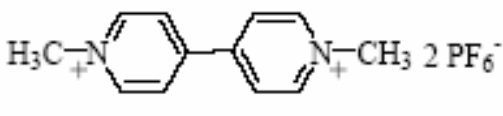

PARAQUAT 15

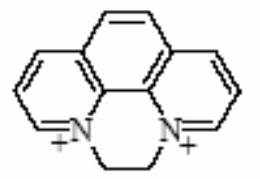

PHENQUAT 16
$2 \mathrm{PF}_{6}{ }^{-}$

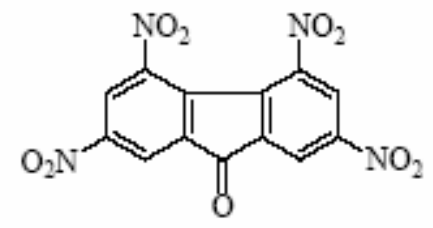

TetNF 17

\section{Figure 6}

The complexes formed readily. Addition of a molar equivalent of $\mathbf{1 0}$ in chloroform to a molar equivalent of the quats in acetone immediately produced a change in the colour of the solution to 
purple in case of paraquat and brown for phenquat. The change in colour is attributable to charge transfer between the electron rich naphthyl units of 1,4-DN34C10 and the electron-deficient quats. The solutions were then set aside for crystallisation. Paraquat gave deep purple, and phenquat, brown coloured crystals. The host-guest stoichiometry was analysed and found to be 1 $: 1$ by elemental analysis. The FAB mass spectra of the paraquat and phenquat complexes gave the $\mathrm{M}^{+}$peaks at $\mathrm{m} / \mathrm{z} 1112$ and 1134 , respectively. The peaks corresponding to the $[1,4-$ DN34C10•quatPF6] $]^{+}$ion formed as a result of the loss of one PF6ion from the $1: 1$ complexes appeared at $\mathrm{m} / \mathrm{z} 967$ and 989 , respectively.

Table 1. ${ }^{1} \mathrm{H}$ NMR chemical shift data ( $\delta$ values) in acetone- $\mathrm{d}_{6}$

\begin{tabular}{ccccccc}
\hline Compound /Complex & \multicolumn{3}{c}{ Paraquat } & \multicolumn{3}{c}{ 1,4-DN34C10 } \\
\hline & $\mathrm{H}-2,6$ & $\mathrm{H}-3,5$ & $\mathrm{~N}^{+} \mathrm{Me}$ & $\mathrm{H}-5,8$ & $\mathrm{H}-6,7$ & $\mathrm{H}-2,3$ \\
Paraquat & 9.36 & 8.82 & 4.71 & & & \\
DN34C10 & & & & 8.18 & 7.39 & 6.53 \\
Complex & 8.87 & 7.80 & 4.68 & 7.80 & 7.42 & 6.23 \\
\hline
\end{tabular}

The ${ }^{1} \mathrm{H}$ NMR spectra of both complexes were recorded in acetone- $\mathrm{d}_{6}$ and the chemical shift data are listed in Tables $1 \& 2$. Comparison of the ${ }^{1} \mathrm{H}$ NMR spectral data of these complexes with those of the constituents indicated a dramatic upfield shift for the quat protons as well as the crown protons, particularly, the H-2, H-6 doublet in paraquat and the H-2, H-3 singlet of the naphthyl ring of the crown. The large chemical shifts induced by the macrocyclic host on the guests as well as by the guests on the host are indicative of the inclusion of the guest into the cavity of the host.

Table 2. ${ }^{1} \mathrm{H}$ NMR chemical shift data ( $\delta$ values) in acetone- $\mathrm{d}_{6}$

Compound /Complex

Phenquat

$1,4-\mathrm{DN} 34 \mathrm{C} 10$

$\mathrm{H}-2,9 \quad \mathrm{H}-4,7 \quad \mathrm{H}-3,5,6,8 \quad \mathrm{~N}^{+}-\mathrm{CH}_{2} \quad \mathrm{H}-5,8 \quad \mathrm{H}-6,7 \quad \mathrm{H}-2,3$

$\begin{array}{lllll}\text { Phenquat } & 9.97 & 9.80 & 8.97 & 6.05\end{array}$

DN34C10

$\begin{array}{llll}9.97 & 9.80 & 8.97 & 6.05\end{array}$

Complex

$9.57 \quad 9.30$

8.63

5.63

$8.18 \quad 7.39$

6.53

The 2,4,5,7-tetranitrofluorenone (TetNF) complex with 1,4-DN34C10 was prepared by mixing the host in chloroform with TetNF in ethanol. The color of the solution changed to black on warming which was again an indication of the formation of a charge transfer complex. The ${ }^{1} \mathrm{H}$ NMR spectrum of the complex showed small changes in chemical shifts of the host and guest 
protons, probably due to weak association of the host and guest (Table 3).

Table 3. ${ }^{1} \mathrm{H}$ NMR chemical shift data ( $\delta$ values) in acetone- $\mathrm{d}_{6}$

\begin{tabular}{cccccc}
\hline Compound /Complex & \multicolumn{2}{c}{ TetNF } & \multicolumn{3}{c}{$1,4-\mathrm{DN} 34 \mathrm{C} 10$} \\
\hline & $\mathrm{H}-3,6$ & $\mathrm{H}-1,8$ & $\mathrm{H}-5,8$ & $\mathrm{H}-6,7$ & H-2,3 \\
TetNF & 9.06 & 8.92 & & & \\
DN34C10 & & & 8.18 & 7.39 & 6.53 \\
Complex & 9.04 & 8.68 & 8.07 & 7.36 & 6.45 \\
\hline
\end{tabular}

\section{Evaluation of binding constants}

In order to further understand the host-guest interactions involved in the above complexes, we attempted to quantify them. 'H NMR spectroscopy has been extensively employed to determine binding constants of complex formation in host-guest complexes. ${ }^{26}$ The method involves titration of host until there is no significant change in the chemical shift of a monitored signal in successive NMR spectra. Then the observed chemical shift of the monitered signal $\delta_{\text {obsd }}$ is given by

$$
\begin{aligned}
& \delta_{\text {obsd. }}=\delta_{\mathrm{h}}-\left(\Delta \delta_{\max } / 2\right)\left(\mathrm{b}-\sqrt{ } \mathrm{b}^{2}-4 \mathrm{R}\right) \\
& \Delta \delta=\delta_{\mathrm{h}}-\delta_{\text {obsd }}=\Delta \delta_{\max } / 2\left(\mathrm{~b}-\sqrt{ } \mathrm{b}^{2}-4 \mathrm{R}\right) . \\
& \text { where } \mathrm{R}=[\mathrm{Go}] /[\mathrm{Ho}] \\
& \mathrm{b}=1+\mathrm{R}+1 / \mathrm{K}[\mathrm{Ho}]
\end{aligned}
$$

Variation of $\delta_{\text {obsd }}$ with respect to changes in the host-guest ratio (R) forms the basis of the NMR titration technique for the determination of $\mathrm{K}$ values. Equation 1 has two unknown parameters, $\Delta \delta_{\max }$ and $\mathrm{K}$. Using an iterative non-linear curve fitting technique, the values of $\mathrm{K}$ and $\Delta \delta_{\max }$ that best simulate the experimental set of data $(\Delta \delta$ and $\mathrm{R})$ can be determined, as reported by Macomber. ${ }^{27}$ 


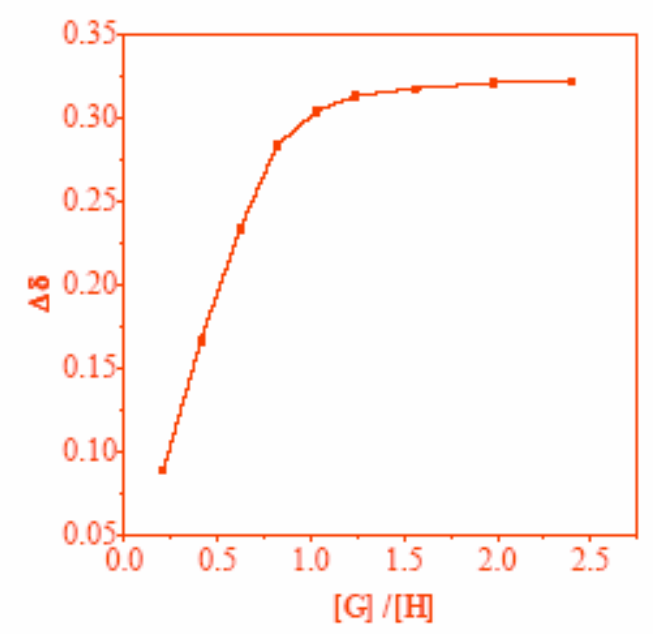

Figure 7. Titration curve of paraquat. $2 \mathrm{PF}_{6}$ versus $1,4-\mathrm{DN} 34 \mathrm{C} 10$.

We chose to evaluate the binding constants of the complexes utilising the above methodology. The titration curves of 1,4-DN34C10 for interaction with guests paraquat 15 and phenquat 16 were obtained by plotting $(\Delta \delta$ versus $\mathrm{R})$ the data being obtained from the direct titration of a known concentration of the host with increasing amounts of the corresponding guest. As is evident from the titration curves (Fig. 7 and Fig. 8) both the quats show a break in the curve as the guest concentration equals that of the host. This is a strong indicator of $1: 1$ binding. ${ }^{28}$

However, it was found that the data obtained were inadequate for the purpose of determination of the binding constants due to excessive saturation. So the alternative protocol of dilution was adopted. ${ }^{28}$ An equimolar solution of the host and the guest was prepared and its spectrum was recorded. The solution was then progressively diluted and successive spectra were recorded. The ratio of the host to guest was thus constant throughout the experiment. Both the sets of data were combined and the binding constants were evaluated using equation 1, which was fitted employing the Sigma plot curve fitting routine (see experimental section for details). The binding constants $(\mathrm{K})$ and $\Delta \delta_{\max }$ thus obtained are listed in Table 4. 


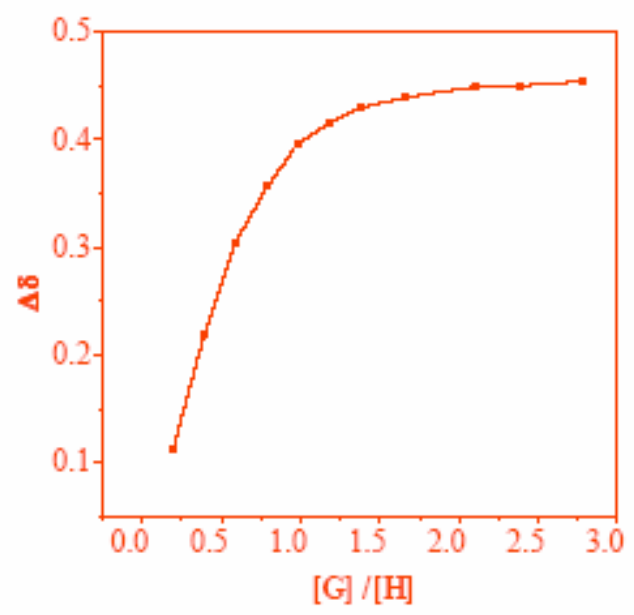

Figure 8. Titration curve of phenquat. $2 \mathrm{PF}_{6}$ versus $1,4-\mathrm{DN} 34 \mathrm{C} 10$.

Table 4. Binding constants and $\Delta \delta$ max values of 1,4-DN34C10 complexes

\begin{tabular}{|c|c|c|}
\hline Guest & $\mathrm{K}\left(\mathrm{M}^{-1}\right)$ & $\Delta \delta_{\max }$ \\
\hline paraquat & $6.62 \pm 0.81 \times 10^{3}$ & $0.334 \pm 0.007$ \\
phenquat & $2.27 \pm 0.33 \times 10^{3}$ & $0.465 \pm 0.010$ \\
TetNF & $9.71 \pm 2.17$ & $0.537 \pm 0.082$ \\
\hline
\end{tabular}

As is evident from the $\mathrm{K}$ values, both the quats show strong binding and the host-guest stoichiometry is $1: 1$.

The titration curve of tetranitrofluorenone versus 1,4-DN34C10 obtained by the direct titration method did not show any signs of saturation even at a host : guest ratio of $1: 4$ (Fig. 9). Also, the changes in chemical shifts were lower than those obtained for the quats. The stoichiometry of the complex in solution could not be ascertained directly from the titration curve. It was therefore determined by Job's method (Fig. 10). ${ }^{29}$

The plot indicated a host:guest stoichiometry of 1:1 in solution. The NMR titration results mentioned earlier analysed by the curve fitting software assuming a 1:1 stoichiometry gave a $\mathrm{K}$ value of $9.71 \pm 2.17 \mathrm{M}^{-1}$ and the $\Delta \delta_{\max }$ was $0.537 \pm 0.082$. The low value of $\mathrm{K}$ and the nonsaturating nature of the titration curve indicate that the binding is weak. 


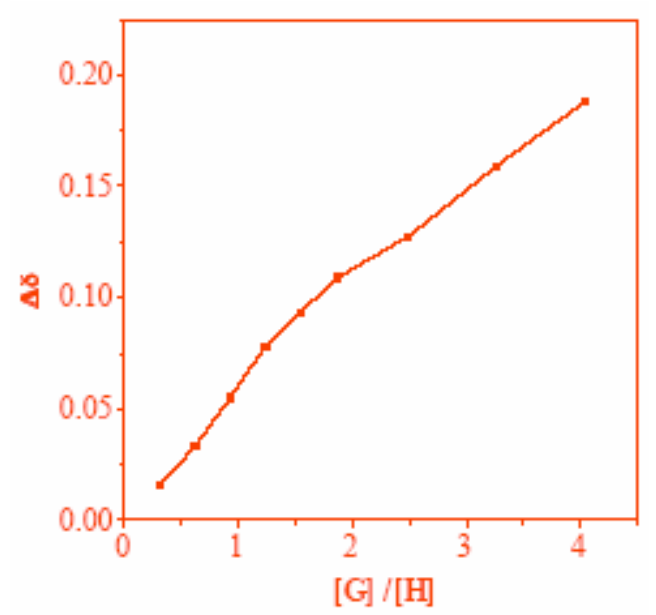

Figure 9. Titration curve of TetNF versus 1,4-DN34C10.

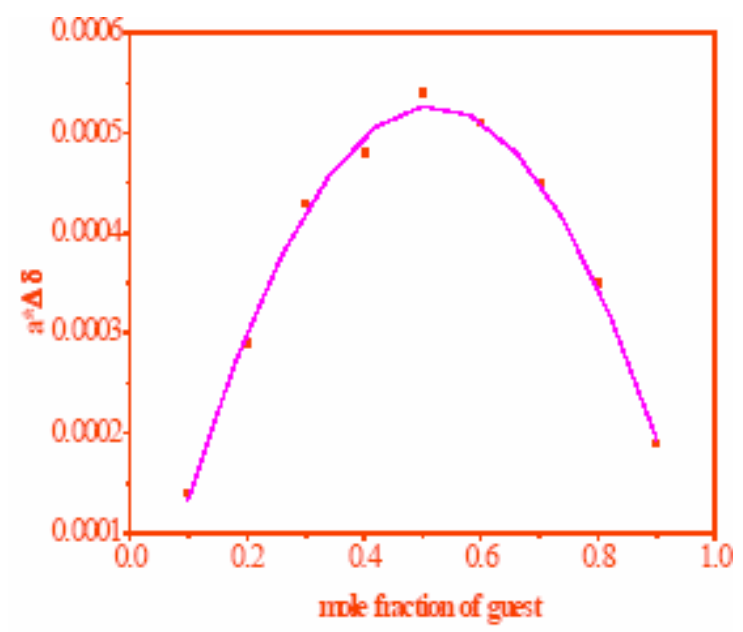

Figure 10

This paper highlights a short and facile synthesis of the versatile host 1,4-DN34C10. From the preliminary crystal structure data, the host was found to support a preformed cavity for guest binding even in the solid state. Although it forms complexes with electron deficient neutral charged organic guests, the complexes with charged guests have higher binding constants than those with neutral guests.

\section{Experimental Section}

General Procedures. All solvents were dried by using appropriate drying agents prior to use. The reagents were purified by employing standard purification techniques. All moisture sensitive reactions were carried out under nitrogen atmosphere. Reagents were transferred using the standard septa-syringe techniques while carrying out dry reactions. 50\% Sodium hydride was used for generating the corresponding phenoxide or alkoxide. It was generally washed with dry 
hexane prior to the addition of the substrate. After the appropriate workup, the organic extracts were washed with water, followed by brine and all organic extracts were dried over anhydrous $\mathrm{MgSO}_{4}$.

Melting points were determined on a SUPERFIT melting point apparatus and are uncorrected. IR spectra were recorded on PERKIN-ELMER Model 1310 or JASCO FTIR 5300 instruments. Solid samples were prepared as $\mathrm{KBr}$ wafers and liquid samples as a film between $\mathrm{NaCl}$ plates. ${ }^{1} \mathrm{H}$ NMR (100, 200 and $500 \mathrm{MHz}$ ) and ${ }^{13} \mathrm{C}$ NMR (25 and $50 \mathrm{MHz}$ ) spectra were recorded on JEOL FX-100, BRUKER AF-200 and ACP 500 NMR spectrometers in chloroformd solutions with tetramethylsilane (TMS) as an internal standard, unless otherwise stated. Elemental analyses were obtained using PERKINELMER model 240C-CHN analyzer. The FAB mass spectra were recorded on JEOL SX102 mass spectrometer at CDRI, Lucknow. Mass spectra were recorded on VG 70-70H instrument at IICT, Hyderabad.

4-Bromonaphthol ${ }^{23 a}$ was benzylated by treating it with benzyl chloride and potassium carbonate in DMF for $18 \mathrm{~h}$ to obtain 11 (yield 83\%, m.p. $78-80{ }^{\circ} \mathrm{C}$ ).

1,11-Bis(4'-benzyloxynaphthyloxy)-3,6,9-trioxaundecane (12). ${ }^{23 \mathrm{~b}}$ To a stirred suspension of sodium hydride $(3.38 \mathrm{~g}, 70 \mathrm{mmol})$ in DMF $(50 \mathrm{ml})$, was added tetraethylene glycol $(6.82 \mathrm{~g}$, $35 \mathrm{mmol}$ ) and the mixture was stirred at room temperature for an hour. To this mixture, 4bromobenzyloxynaphthalene 11 (7.20 g, $70 \mathrm{mmol})$ in $50 \mathrm{~mL}$ DMF was added, followed by CuI $(5.90 \mathrm{~g}, 31 \mathrm{mmol})$ and the reaction mixture heated at $120^{\circ}$ for $48 \mathrm{~h}$. Usual workup followed by column chromatography yielded $12(8.80 \mathrm{~g}, 38 \%)$ as a solid and $\mathbf{1 3}(7.50 \mathrm{~g}, 50 \%)$ as oil.

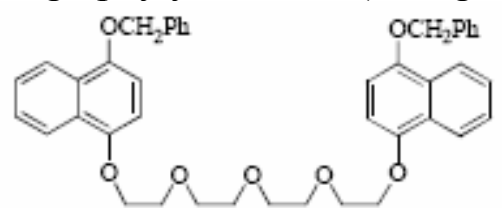

12

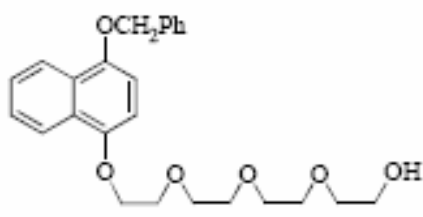

13

12. $\mathrm{Mp} 62{ }^{\circ} \mathrm{C}(\mathrm{MeOH})$; IR (KBr): 3040, 2836, 1580, 1450, 1360, 1270, 1240, 1100, 1050, 800, $770 \mathrm{~cm}^{-1} ;{ }^{1} \mathrm{H}$ NMR $(200 \mathrm{MHz}): \delta 8.30-8.21(\mathrm{~m}, 4 \mathrm{H}), 7.69-7.36(\mathrm{~m}, 14 \mathrm{H}), 6.73-6.64(\mathrm{q}, 4 \mathrm{H})$, $5.17(\mathrm{~s}, 4 \mathrm{H}), 4.24-4.18(\mathrm{t}, 4 \mathrm{H}), 3.98-3.92(\mathrm{t}, 4 \mathrm{H}), 3.80-3.71(\mathrm{~m}, 8 \mathrm{H}) ;{ }^{13} \mathrm{C} \mathrm{NMR}(25 \mathrm{MHz}): \delta$ $148.89,148.72,139.54,128.60,127.89,127.42,126.65,125.95,122.01,104.89,104.77,70.89$, 70.77, 70.36, 70.56, 69.89, 68.24. Analysis: Calc. for $\mathrm{C}_{42} \mathrm{H}_{42} \mathrm{O}_{7}, \mathrm{C}, 76.57$; $\mathrm{H}, 6.43$, Found: C,76.55; H,6.43.

13. IR (neat): $3400,3060,2836,1590,1450,1370,1270,1240,1070,800,750,720 \mathrm{~cm}^{-1} ;{ }^{1} \mathrm{H}$ NMR (200 MHz): $\delta 8.31-8.21(\mathrm{~m}, 2 \mathrm{H}), 7.53-7.32(\mathrm{~m}, 7 \mathrm{H}), 6.78-6.67(\mathrm{q}, 2 \mathrm{H}), 5.19(\mathrm{~s}, 2 \mathrm{H}), 4.29-$ $4.21(\mathrm{t}, 2 \mathrm{H}), 4.0-3.92(\mathrm{t}, 2 \mathrm{H}), 3.82-3.72(\mathrm{t}, 2 \mathrm{H}), 3.69-3.66(\mathrm{~m}, 8 \mathrm{H}), 3.63-3.60(\mathrm{t}, 2 \mathrm{H})$.

1,11-Bis(4'-hydroxynaphthyloxy)-3,6,9-trioxaundecane (14). The dibenzyl ether 12 (500 mg, $0.76 \mathrm{mmol})$ was hydrogenated with $20 \% \mathrm{Pd}(\mathrm{OH})_{2} / \mathrm{C}$ (Pearlman catalyst) ${ }^{24}(180 \mathrm{mg})$ in ethyl acetate at 55 psi pressure in a Parr apparatus for $6 \mathrm{~h}$. The catalyst was then filtered off and washed thoroughly with ethyl acetate. After evaporation of the solvent, the crude product was subjected to flash chromatographic purification to obtain $\mathbf{1 4}$ as brown oil. An analytical sample 
of 14 could not be obtained. But the above material proved to be suitable enough for further transformation.

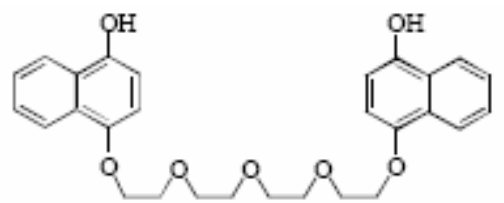

14

14. Yield: $290 \mathrm{mg}, 80 \%$; IR (neat): 3260, 3060, 2860, 1580, 1440, 1320, 1260, 1060, 940, 800, 750, $720 \mathrm{~cm}^{-1} ;{ }^{1} \mathrm{H}$ NMR (200 MHz): $\delta$ 8.24-8.13 (m, 4H), 7.50-7.44 (m, 4H), 6.66-6.61(d, 4H), 6.46-6.41 (d, 2H), 4.13-4.08 (t, 4H), 3.94-3.89 (t, 4H), 3.72-3.69 (d, 8H). ${ }^{13} \mathrm{C}$ NMR (25 MHz): $\delta$ $148.24,145.95,126.48,122.59,122.06,121.83,108.06,105.86,70.65,70.01,67.89$.

Synthesis of DN34C10, (10). a) To a stirred suspension of sodium hydride (80 $\mathrm{mg}, 1.68 \mathrm{mmol})$ in DMF (2 ml) was added dinaphthol $14(400 \mathrm{mg}, 0.84 \mathrm{mmol})$ dropwise in $2 \mathrm{~mL}$ DMF. The mixture was stirred at $\mathrm{rt}$ for $30 \mathrm{~min}$. To this tetraethylene glycol ditosylate (472 $\mathrm{mg}, 0.84 \mathrm{mmol}$ ) in $2 \mathrm{ml} \mathrm{DMF}$ was added and the reaction mixture was heated at $80{ }^{\circ} \mathrm{C}$ for $72 \mathrm{~h}$. It was then quenched with water and extracted with dichloromethane. The dried organic layer was evaporated and the crude product was chromatographed to obtain DN34C10 as a white solid. Yield: $50 \mathrm{mg}, 9 \%$.

b) The dinaphthol (455 $\mathrm{mg}, 0.95 \mathrm{mmol})$ and tetraethylene glycol ditosylate (477 $\mathrm{mg}$, $0.95 \mathrm{mmol}$ ) in $60 \mathrm{~mL}$ of DMF were added over a period of $3 \mathrm{~h}$ to a stirred and heated suspension of sodium hydride $(100 \mathrm{mg}, \sim 2 \mathrm{mmol})$ in $50 \mathrm{~mL}$ DMF. The reaction mixture was heated at $110{ }^{\circ} \mathrm{C}$ for a period of $72 \mathrm{~h}$. The solvent was then removed from the reaction mixture under vacuum and was water added to quench the reaction mixture. The organic components were extracted with chloroform. The crude product mixture obtained on the evaporation of the solvent was chromatographed to give pure 10. Yield: $165 \mathrm{mg}, 27 \%$.

c) To a stirred mixture of $\mathrm{Cs}_{2} \mathrm{CO}_{3}(2.60 \mathrm{~g}, 8 \mathrm{mmol})$, CsOTs $(245 \mathrm{mg}, 0.80 \mathrm{mmol})$ and $\mathrm{nBu} \mathrm{NI}_{4}$ $(20 \mathrm{mg})$ in $80 \mathrm{~mL}$ of DMF at $110{ }^{\circ} \mathrm{C}$ was added a mixture of dinaphthol 14 (380 $\left.\mathrm{mg}, 0.80 \mathrm{mmol}\right)$ and tetraethylene glycol ditosylate $(400 \mathrm{mg}, 0.80 \mathrm{mmol})$ in $40 \mathrm{~mL}$ DMF dropwise over $3 \mathrm{~h}$. The reaction mixture was further heated for $36 \mathrm{~h}$ at $110{ }^{\circ} \mathrm{C}$. DMF was removed from the reaction mixture under reduced pressure and the resultant residue was partitioned between chloroform and water, the organic layer dried and concentrated. The crude product was chromatographed to furnish pure $10{ }^{25}$ Yield: $165 \mathrm{mg} \mathrm{32 \% .} \mathrm{mp} 100101{ }^{\circ} \mathrm{C}(\mathrm{MeOH})$; IR (KBr): 3049, 2870, 1595 , 1466, 1452, 1392, 1275, 1240, 1099, 1022, 952, 794, 765, $750 \mathrm{~cm}^{-1} ;{ }^{1} \mathrm{H}$ NMR $(200 \mathrm{MHz}): \delta .18-$ $8.13(\mathrm{~m}, 4 \mathrm{H}), 7.37-7.26(\mathrm{~m}, 4 \mathrm{H}) 6.42(\mathrm{~s}, 4 \mathrm{H}), 4.10-4.04(\mathrm{t}, 8 \mathrm{H}), 3.93-3.88(\mathrm{t}, 8 \mathrm{H}), 3.75-3.74(\mathrm{~d}$, $16 \mathrm{H}) ;{ }^{13} \mathrm{C}$ NMR $(25 \mathrm{MHz}): \delta 148.83,126.60,125.77,121.94,104.95,70.89,69.83,68.30$; Analysis: Calc. for $\mathrm{C}_{34} \mathrm{H}_{44} \mathrm{O}_{10}$ : C,67.90; H,6.97, Found: C,67.82; H,6.91. Mass: $\mathrm{M}^{+}$ion at $\mathrm{m} / \mathrm{z}$ 636.

\section{Complexation studies - preparation of the guests}

1,1'-Dimethyl-4,4'-bipyridinium diiodide or paraquat diiodide ${ }^{30 a}$. To a stirred solution of 4,4-bipyridyl (150 mg, $0.96 \mathrm{mmol})$ in $1 \mathrm{~mL} \mathrm{MeOH}$ under nitrogen was added methyl iodide 
(545 mg, $3.84 \mathrm{mmol}$ ) and the reaction mixture stirred overnight at $\mathrm{rt}$. The bright orange colored crystals obtained were filtered off. It was then recrystallized from acetone-water (crystallized on cooling). Yield: $384 \mathrm{mg}, 90 \%$. Analysis: Calc. for $\mathrm{C}_{12} \mathrm{H}_{14} \mathrm{~N}_{2} \mathrm{I}_{2}$ : C, 32.75; H, 3.21; N, 6.36, Found: C, 33.00; H, 3.35; N, 6.38.

1,1'-Dimethyl-4,4'-bipyridinium bis(hexafluorophosphate) or paraquat bis(hexafluorophosphate) (15). ${ }^{30 \mathrm{~b}}$ Paraquat diiodide $(230 \mathrm{mg}, 0.523 \mathrm{mmol})$ was dissolved in water $(15 \mathrm{~mL})$ and ammonium hexafluorophosphate $(170 \mathrm{mg}, 1.04 \mathrm{mmol})$ was added. The contents were warmed to obtain a clear solution and allowed to cool. The hexafluorophosphate salt crystallised out as pale yellow needles. Yield: $200 \mathrm{mg}, 80 \%$. H NMR (200 MHz, acetone-d6): $\delta$ 9.36-9.33 (d, 4H), 8.82-8.79 (d, $4 \mathrm{H}), 4.71(\mathrm{~s}, 6 \mathrm{H})$.

5,6-Dihydropyrazino[1,2,3,4-lmn][1,10]phenanthrolinediium dibromide ${ }^{31 \mathrm{a}} \cdot 1$,10-Phenanthroline (900 $\mathrm{mg}, 5 \mathrm{mmol}$ ) was refluxed in excess of 1,2-dibromoethane for $30 \mathrm{~min}$. The reaction mixture was then cooled to rt and water added to it. The product, which passed into the aqueous layer, was separated and evaporated. The residue was recrystallised from EtOH. Yield: $392 \mathrm{mg}, 20 \%$.

5,6-Dihydropyrazino[1,2,3,4-lmn][1,10]phenanthrolinediium bis(hexafluorophosphate) (16)

31b. The dibromide $(184 \mathrm{mg}, 0.5 \mathrm{mmol})$ was dissolved in $10 \mathrm{~mL}$ of water and to this a solution of ammonium hexafluorophosphate $(170 \mathrm{mg}, 1.04 \mathrm{mmol})$ was added. The resulting solution was boiled and then filtered to remove any undissolved material. It was then set aside to allow crystallisation. The salt crystallised as pale brown needles. Yield: $190 \mathrm{mg}, 76 \%$. ${ }^{1} \mathrm{H}$ NMR (200 MHz, acetone- $\left.\mathrm{d}_{6}\right): \delta$ 9.97-9.94 (d, 2H), 9.80-9.76 (d, 2H), 8.97-8.86 (m, 4H), $6.05(\mathrm{~s}, 4 \mathrm{H})$. Analysis: Calc. for $\mathrm{C}_{14} \mathrm{H}_{12} \mathrm{~N}_{2} \mathrm{P}_{2} \mathrm{~F}_{12}$ : C, 34.85; H, 2.33; N, 5.42, Found: C, 33.75; H, 2.42; N, 5.62. 2,4,5,7-Tetranitrofluorenone (17). Fluorenone was nitrated using fresh fuming nitric acid as reported in the literature. ${ }^{32} \mathrm{mp} 244-46{ }^{\circ} \mathrm{C}$ (lit. 249-253 ${ }^{\circ} \mathrm{C}$ ) ${ }^{32},{ }^{1} \mathrm{H}$ NMR (200 MHz): $89.06-9.04$ (d, $2 \mathrm{H}), 8.92-8.91(\mathrm{~d}, 2 \mathrm{H})$.

\section{Preparation of 15 and DN34C10 complex ${ }^{10}$}

Paraquat bis(hexafluorophosphate) $(17 \mathrm{mg}, 0.0357 \mathrm{mmol})$ in $3 \mathrm{~mL}$ of acetone was added to a solution of DN34C10 (23 mg, $0.0357 \mathrm{mmol})$ in $1 \mathrm{~mL}$ chloroform and the resulting purple colored solution was filtered to remove any insoluble material. Pentane was layered on top of this solution and the dark purple colored crystals obtained on standing were filtered off. A weak charge transfer absorption band is observed at $\lambda=504 \mathrm{~nm}$. Yield: $30 \mathrm{mg}, 75 \%$. ${ }^{1} \mathrm{H}$ NMR (200 MHz, acetone- $\left.\mathrm{d}_{6}\right): \delta 8.87-8.30(\mathrm{~d}, 4 \mathrm{H}), 7.80-7.75(\mathrm{~m}, 8 \mathrm{H}), 7.42-7.37(\mathrm{~m}, 4 \mathrm{H}), 6.23(\mathrm{~s}, 4 \mathrm{H}), 4.68$ $(\mathrm{s}, 6 \mathrm{H}), 3.87-3.85(\mathrm{~m}, 32 \mathrm{H})$. Analysis: Calc. for $\mathrm{C}_{48} \mathrm{H}_{58} \mathrm{O}_{10} \mathrm{~N}_{2} \mathrm{P}_{2} \mathrm{~F}_{12}$ : C,51.79; H,5.25; N,2.52, Found: C,51.50; H,5.24; N,3.03. FAB mass: $m / z$ 1112, 967, 636.

\section{Preparation of 16 and DN34C10 complex}

To a solution of $16(18 \mathrm{mg}, 0.0357 \mathrm{mmol})$ in $3 \mathrm{ml}$ of acetone was added a solution of DN34C10 (23 $\mathrm{mg}, 0.0357 \mathrm{mmol}$ ) in $2 \mathrm{~mL}$ of chloroform. After ensuring that the resulting solution was clear, pentane was layered on top and the dark brown colored crystals obtained were filtered off. A weak charge transfer absorption band was observed at $\lambda=450 \mathrm{~nm}$. Yield: $25 \mathrm{mg}, 61 \%$. ${ }^{1} \mathrm{H}$ 
NMR (200 MHz, acetone-d6): $\delta$ 9.57-9.55 (d, 2H), 9.30-9.26 (d, 2H), 8.63-8.56 (m, 2H), 8.108.09 (d, 2H), 7.66-7.61 (m, 4H), 7.16-7.11 (m, 4H), $6.14(\mathrm{~s}, 4 \mathrm{H}), 5.63(\mathrm{~s}, 4 \mathrm{H}), 3.91-3.90$ (d, $32 \mathrm{H})$. Analysis: Calc. for $\mathrm{C}_{50} \mathrm{H}_{56} \mathrm{O}_{10} \mathrm{~N}_{2} \mathrm{P}_{2} \mathrm{~F}_{12}$ : C, 52.91; H, 4.97; N, 2.47, Found: C, 52.48; H, 5.15; N, 1.99. FAB mass: $m / z$ 1134, 989, 636 .

Preparation of 2,4,5,7-tetranitrofluorenone (17) and DN34C10 complex. A solution of DN34C10 (25 mg, $0.039 \mathrm{mmol})$ in $4 \mathrm{ml}$ of chloroform was added to a solution of tetranitrofluorenone $(14 \mathrm{mg}, 0.039 \mathrm{mmol})$ in $4 \mathrm{~mL}$ of ethanol-benzene (1:1). The resultant solution was warmed to dissolve all the solids. The solution was left at $\mathrm{rt}$ to allow it to crystallize. The fine black needles obtained were filtered. The analysis of the complex was found to correspond to the 2: 1 ratio of TetNF to host. A weak charge transfer absorption band is observed at $\lambda=485 \mathrm{~nm}$. Yield: $15 \mathrm{mg}, 50 \%$. ${ }^{1} \mathrm{H}$ NMR $\left(200 \mathrm{MHz}\right.$, acetone- $\mathrm{d}_{6}: \delta 9.04-9.03(\mathrm{~d}, 2 \mathrm{H})$, 8.68-8.08 (d, 2H), 8.01-8.02 (m, 4H), 7.36-7.31 (m, 4H), 6.45 (s, 4H), 4.10-4.01 (m, 8H), 3.99$3.89(\mathrm{~m}, 8 \mathrm{H}), 3.72-3.66(\mathrm{~m}, 16 \mathrm{H})$. Analysis: Calc. for $\mathrm{C}_{62} \mathrm{H}_{52} \mathrm{O}_{28} \mathrm{~N}_{2}$ : C, 54.87; H, 3.86; N, 8.25, Found: C, 55.10; H, 4.08; N, 7.55. FAB mass: $m / z$ 1310, 636.

\section{Experimental procedure for NMR titration}

All ${ }^{1} \mathrm{H}$ NMR titration experiments were recorded on a BRUKER AF-200 NMR spectrometer in acetone- $\mathrm{d}_{6}$ at $25{ }^{\circ} \mathrm{C}$. The titrations were done by both methods i.e., by saturating the host solution with the guest and by the dilution protocol.

A sample containing a known amount of the host in a known volume of the solvent was taken in an NMR tube and the spectrum recorded. To this sample, a known quantity of the guest was added and the spectrum recorded again. The process was repeated. Typically eight to ten spectra were recorded for each determination of the association constant $\mathrm{K}$. The host concentration was of the order of $10^{-2} \mathrm{M}$ and the guest concentrations ranged from $10^{-3}$ to $10^{-2} \mathrm{M}$. The $\Delta \delta$ values were calculated by substracting the chemical shift of the mixture from that of the pure host. The aromatic signal of the host monitored for the determination of the $\Delta \delta$ values was the H-2, H-3 singlet which was well separated from other resonances and convenient to monitor. The titration curve of the $\Delta \delta$ vs the guest to host ratio was plotted, to obtain information about the stoichiometry of the complexes.

For the dilution protocol, an equimolar solution of the host and the guest, was made by dissolving them in a known volume of acetone- $\mathrm{d}_{6}$. The NMR spectrum of the sample was recorded. The solution was then diluted by adding a known volume of acetone- $\mathrm{d}_{6}$ and the spectrum was recorded again. The process was continued by progressively diluting the mixture. $\Delta \delta$ values were calculated by taking the difference between the chemical shift of interest in the mixture and the same resonance in the spectrum of the pure host. Both the sets of data were combined and the binding constants evaluated.

Equation 1, given in the results and discussion, was slightly modified for this purpose as follows:

$\delta_{\text {obsd }}-\delta_{\mathrm{h}}=\left(\Delta \delta_{\max } / 2\right)\left(\mathrm{b}-\sqrt{ } \mathrm{b}^{2}-4 \mathrm{R}\right)$

$\Delta \delta=\left(\Delta \delta_{\max } / 2\right)\left(\mathrm{b}-\sqrt{ } \mathrm{b}^{2}-4 \mathrm{R}\right)(2)$ 
Thus, the data were fitted to this non-linear expression using the Sigma plot software routine and the parameters $\mathrm{K}$ and $\Delta \delta_{\max }$ were obtained.

\section{Job's plot for TetNF-DN34C10 complex}

The complex stoichiometry was determined by using Job's method of continuous variations. The method involves preparation of standard solutions of TetNF and DN34C10 (0.013 M in each) in acetone- $\mathrm{d}_{6}$. In 9 separate NMR tubes the solutions of the host and guest were mixed in different proportions such that the ratio of each component varied but the total volume of the mixture was kept constant $(500 \mu \mathrm{l})$, i.e., $[\mathrm{H}]+[\mathrm{G}]$ was kept constant while varying $[\mathrm{H}] /[\mathrm{G}]$. A plot of the product of the host concentration and $\Delta \delta$ vs the guest mole fraction was made. This peaked at the guest mole fraction of 0.5 (the complex concentration would also be maximum at this mole fraction), indicating that the complex has a stoichiometry of $1: 1$ in solution. ${ }^{29}$

\section{Structural data}

The structure was solved by direct methods and refined isotropically to an $\mathrm{R}$ value of 0.14 using 384 above 4 sigma of 1762 reflections. The quality and the quantity of the data were not sufficient for further refinements.

Cell dimensions: Crystal structure analysis indicated that the host crystallized in the space group $\mathrm{P} 21 / \mathrm{n}$, monoclinic, $\mathrm{Z}=2$; cell dimensions: $\mathrm{a}=13.108(3) \AA, \mathrm{b}=5.120(4) \AA, \mathrm{c}=$ $25.201(7) \AA$ and $\beta=102.79^{\circ}(2), \rho_{(\text {cell) }}=1.19 \mathrm{~g} /$ c.c., $V_{(\text {cell })}=1649.3 \AA^{3}$.

$\begin{array}{llllllll}\text { O27 } & 0.45534 & 0.09721 & 0.15052 & \text { C19 } & 0.38070 & -1.19077 & -0.13174 \\ \text { O1 } & -0.06168 & -0.81094 & 0.03274 & \text { C8 } & -0.12794 & -1.73180 & -0.19619 \\ \text { O4 } & -0.17237 & -1.18402 & -0.08173 & \text { C99 } & 0.57571 & -0.79068 & 0.02912 \\ \text { C33 } & 0.06029 & -0.47977 & 0.02226 & \text { C32 } & 0.13517 & -0.28128 & 0.04022 \\ \text { O21 } & 0.67391 & -0.44852 & 0.08679 & \text { C3 } & -0.18387 & -1.06533 & -0.03498 \\ \text { C48 } & 0.34990 & -1.25084 & -0.18972 & \text { C29 } & 0.29032 & 0.04623 & 0.08757 \\ \text { O30 } & 0.24872 & -0.09626 & 0.12318 & \text { C25 } & 0.64122 & -0.00902 & 0.19968 \\ \text { C16 } & 0.45690 & -1.18140 & -0.00433 & \text { C12 } & 0.21269 & -1.73784 & -0.08522 \\ \text { O10 } & 0.04428 & -1.70611 & -0.14676 & \text { C5 } & -0.26115 & -1.31201 & -0.10448 \\ \text { C36 } & 0.11513 & -0.42891 & 0.12909 & \text { C17 } & 0.48987 & -1.03601 & -0.04497 \\ \text { C35 } & 0.03707 & -0.60797 & 0.10908 & \text { C23 } & 0.75179 & -0.17966 & 0.16441 \\ \text { C44 } & 0.46128 & -1.02701 & -0.10454 & \text { C9 } & -0.03696 & -1.91136 & -0.16977 \\ \text { C40 } & -0.01828 & -0.80440 & 0.13768 & \text { C15 } & 0.37031 & -1.34654 & -0.03510 \\ \text { C2 } & -0.08687 & -0.91033 & -0.02245 & \text { C20 } & 0.67161 & -0.57111 & 0.03227 \\ \text { C6 } & -0.25039 & -1.41888 & -0.15989 & \text { C14 } & 0.33696 & -1.38678 & -0.10138 \\ \text { C11 } & 0.13180 & -1.86247 & -0.12465 & \text { C22 } & 0.76330 & -0.31302 & 0.11188 \\ \text { C31 } & 0.16985 & -0.26838 & 0.09296 & \text { C45 } & 0.49003 & -0.85578 & -0.14577 \\ \text { O13 } & 0.26149 & -1.56190 & -0.12297 & \text { C26 } & 0.54712 & 0.22217 & 0.17954 \\ \text { O24 } & 0.66099 & 0.00467 & 0.14748 & \text { C28 } & 0.36501 & 0.27525 & 0.13074 \\ \text { O18 } & 0.57498 & -0.85334 & -0.03113 & \text { C47 } & 0.39230 & -1.06397 & -0.22216\end{array}$




$\begin{array}{llllllll}\text { O7 } & -0.17151 & -1.54342 & -0.15500 & \text { C37 } & 0.15817 & -0.37671 & 0.19169 \\ \text { C46 } & 0.46579 & -0.89858 & -0.20022 & \text { C39 } & 0.02139 & -0.75082 & 0.19548 \\ \text { C34 } & 0.00546 & -0.63915 & 0.05058 & \text { C38 } & 0.09456 & -0.56916 & 0.22026\end{array}$

\section{Acknowledgements}

A. M. thanks UGC (New Delhi) for financial support in the form of research fellowship. Prof. Guru Rao's help with crystal structures is acknowledged.

\section{References}

1. (a) Saenger, W. 'Principles of Nucleic Acid Structure' Springer-Verlag, New York, 1984, p.132; b) Wakelin, L. P. G. Med. Res. Rev. 1986, 6, 275.

2. a) Burley, S. K. and Petsko, G. A. Science 1985, 229, 23; b) Abraham, R. J.; Eivazi F. and Pearson, H. J. Chem. Soc., Chem. Commun. 1976, 698.

3. a) Desiraju, G. R. Current Opinion in Solid State and Material Science 1997, 2, 451454; b) Desiraju, G. R. and Gavezzotti, A. J. Chem. Soc., Chem. Commun. 1989, 621.

4. a) Hunter, C. A. and Sanders, J. K. M. J. Am. Chem. Soc. 1990, 112, 5525; b) Hunter, C. A. Chem. Soc. Rev., 1994, 101 and references cited therein; c) Hunter, C. A. J. Chem. Soc., Chem. Commun. 1991, 749.

5. a) Anderson, S.; Anderson, H. L. and Sanders, J. K. M. Acc. Chem. Res., 1993, 26, 469; b) Stoddart, J. F. 'Template-Directed Synthesis of New Organic Materials', in 'Frontiers in Supramolecular Organic Chemistry and Photochemistry', Schneider, H. J. and Dürr, H. Ed., VCH., New York, 1991, p.251.

6. Foster, R. 'Organic Charge Transfer Complexes', Academic Press, New York, 1969, p. 238.

7. a) Dougherty, D. A.; Stauffer, D. A. Science 1990, 250, 1558; b) Kearney, P. C.; Mizoue, L. S.; Kumpf, R. A.; Forman, J. E.; McCurdy, A. and Dougherty, D. A. J. Am. Chem. Soc. 1993, 113, 9907; c) Dougherty, D. A.; Stauffer, D. A. and Barrons, R. E. J. Org. Chem. 1990, 55, 2762.

8. a) Stoddart, J. F. and Nepogodiev, S.A. Chem. Rev. 1998, 98, 1959; b) Stoddart, J. F.; Balzani, V. and Gomez-Lopez, M. Acc. Chem. Res. 1998, 31, 405 c) Stoddart, J. F. Pure and Appl. Chem. 1988, 60, 467.

9. a) Stoddart, J. F. and Fyle, M. C. T. Acc. Chem. Res. 1997, 30, 393; b) Coloquhoun, H. M.; Goodings, E. P.; Maud, J. M.; Stoddart, J. F.; Wolstenholme, J. B. and Williams, D. J. J. Chem. Soc. Perkin Trans. II 1985, 607.

10. Stoddart, J. F. et al, J. Chem. Soc., Chem. Commun. 1987, 1054, 1058, 1061, 1064, 1066.

11. Slawin, A. M. Z.; Spencer, N.; Stoddart, J. F. and Williams, D. J. J. Chem. Soc., Chem. Commun. 1987, 1070. 
12. a) Odell, B.; Reddington, M. V.; Slawin, A. M. Z.; Spencer, N.; Stoddart, J. F. and Williams, D. J. Angew. Chem. Int. Ed. Engl. 1988, 27, 1547; b) Ashton, P. R.; Reddington, M. V.; Slawin, A. M. Z.; Odell, B.; Stoddart, J. F. and Williams, D. J. Angew. Chem. Int. Ed. Engl. $1988,27,1550$.

13. a) Ortholand, J.-Y.; Slawin, A. M. Z.; Spencer, N.; Stoddart, J. F. and Williams, D. J. Angew. Chem. Int. Ed. Engl. 1989, 28, 1394; b) Ashton, P. R.; Chrystal, E. J. T.; Mathias, J. P.; Parry, K. P.; Slawin, A. M. Z.; Spencer, N.; Stoddart, J. F. and Williams, D. J. Tetrahedron Lett. 1987, 28, 6367.

14. Amballino, D. B. and Stoddart, J. F. Chem. Rev. 1995, 95, 2725.

15. a) Philp, D. and Stoddart, J. F. Angew. Chem. Int. Ed. Engl. 1996, 35, 1154; b) Owen, G. J. and Hodge, P. Chem. Commun. 1997, 11; c) Stoddart, J. F.; Asakawa, M.; Ashton, P. R.; Ballardini, R.; Balzani, V.; Belohradsky, M.; Gandolfi, M. T.; Kocian, O.; Prodi, L.; Raymo, F. M. and Venturi, M. J. Am. Chem. Soc. 1997, 119, 302.

16. a) Stoddart, J.F. Chem. Rev. 1999, 99, 1643; b) Sauvage, J.-P. and Dietrich-Buchecker, C. Molecular Catennanes, Rotaxanes and Knots, Wiley-VCH, Weinheim, 1999 ; Ashton, P. R.; Goodnow, T. T.; Kaifer, A. E.; Reddington, M. V.; Slawin, A. M. Z.; Spencer, N.; Vicent, C.; Stoddart, J. F. and Williams, D. J. Angew. Chem. Int. Ed. Engl. 1989, 28, 1396; c) Brown, C. L.; Philp, D.; Spencer, N. and Stoddart, J. F. Isr. J. Chem. 1992, 32, 61.

17. a) Philp, D.; Brown, C. L. and Stoddart, J. F. Synlett. 1991, 459, 462; b) Anelli, P. L.; Ashton, P. R.; Kaifer, A. E.; Philp, D.; Reddington, M. V.; Slawin, A. M. Z.; Spencer, N.; Prodi, L.; Pietraszkiewicz, M.; Vicent, C.; Stoddart, J. F. and Williams, D. J. J. Am. Chem. Soc. 1992, 114, 193; c) Asakawa, M.; Ashton, P. R.; Boyd, S. E.; Brown, C. L.; Gillard, R. E.; Kocian, O.; Raymo, F. M.; Stoddart, J. F.; Tolley, M. S.; and White, A. J. P. J. Org. Chem. 1997, 62, 26.

18. Ashton, P. R.; Kaifer, A. E.; Philp, D.; Slawin, A. M. Z.; Spencer, N.; Amballino, D. B.; Rutland, M. T.; Newton, S. P.; Raymo, F. M.; Brown, C. L.; Pietraszkiewicz, M.; Vicent, C.; Stoddart, J. F. and Williams, D. J. J. Am. Chem. Soc. 1995, 117, 1271.

19. Laurent, H. B.; Castellan, A.; Daney, M.; Desvergne, J. P.; Guinand, P.; Marsau, P. and Riffaud, M. H. J. Am. Chem. Soc. 1986, 108, 315.

20. Marquis, D.; Desvergne, J. P. and Laurent, H. B. J. Org. Chem. 1995, 60, 7984.

21. Marquis, D.; Desvergne, J. P.; Marsau, P.; Heinze, B. and Cotrait, M. Tetrahedron Lett. 1996, 37, 5499.

22. Stoddart, J. F.; Williams, D. J.; Spencer, N.; Allwood, B. L. and Zavareh, H. S. J. Chem. Soc., Chem. Commun. 1987, 1061 and 1064.

23. a) Militzer, W. J. Am. Chem. Soc. 1938, 60, 256; b) Bacon, R. G. R. and Rennison, S. C. J. Chem. Soc. (C), 1969, 312.

24. Pearlman, W. M. Tetrahedron Lett. 1967, 1663.

25. Ashton, P. R.; Brown, C. L.; Chrystal, E. J. T.; Parry, K. P.; Pietraszkiewicz, M.; Spencer, N. and Stoddart, J. F. Angew. Chem. Int. Ed. Engl. 1991, 30, 1042.

26. Wang, T.; Bradshaw, J. S. and Izatt, R. M. J. Heterocyclic Chem. 1994, 31, 1097. 
27. Macomber, R. S. J. Chem. Ed. 1992, 69, 375.

28. Wilcox, C. S. Efficacious Functional Group Dyad. NMR in Host-Guest Interactions, in Frontiers in Supramolecular Organic Chemistry and Photochemistry, Schneider, H. J. and Dürr, H. Ed., VCH, New York, 1990, p. 123.

29. (a) Job, A. Annales de chimie (10th series), 1928, 9, 113. (b). Connors, K. A. Binding Constants, Wiley: New York, 1987. (c) Gil, V. M. S.; Olivira, N. C. J. Chem. Ed. 1990, 67, 473.

30. a) Häring, M. Helv. Chim. Acta. 1963, 46, 2970; b) Megehee, E. G. and Johnson, C. E. Inorg. Chem. 1989, 28, 2423.

31. (a) Dickeson, J. E.; Summers, L. A. Aust. J. Chem. 1970, 23 1023. (b) Luong, J. C. Nadjo, L.; Wrighton, M. S. J. Am. Chem. Soc. 1978, 100, 5790.

32. Newman, M. S.; Boden, H. Org. Synth. Coll. 1973, Vol. V, p. 1029. 